\title{
Variability of mass and content of mineral elements in grains of the common bean cultivar Pérola
}

\section{Variabilidade da massa e do teor de elementos minerais dos grãos de feijão cultivar Pérola}

\author{
Pedro Marques da SILVEIRA'; Marcos Antônio Machado MESQUITA2; Augusto Cesar de Oliveira \\ GONZAGA ${ }^{3}$; Tatiely Gomes BERNARDES ${ }^{4}$; Paulo Cesar Ribeiro da CUNHA ${ }^{5}$
}

\author{
${ }^{1}$ Autor para correspondência. Engenheiro Agrônomo, Doutor em Agronomia (Solos e Nutrição de Plantas); Embrapa \\ Arroz e Feijão, Caixa Postal 179, 75375-000, Santo Antônio de Goiás, GO, Brasil; pedro.silveira@embrapa.br \\ 2 Engenheiro Agrônomo, Doutor em Agronomia (Solo e Água); IF Pernambucano-Campus Barreiros, Fazenda Sapé s/n, \\ Zona Rural, 55560-000, Barreiros, PE, Brasil; marcos_a_mesquita@yahoo.com.br \\ ${ }^{3}$ Engenheiro Agrônomo; Embrapa Arroz e Feijão, Santo Antônio de Goiás; augusto.gonzaga@embrapa.br \\ ${ }^{4}$ Engenheira Agrônoma, Doutora em Agronomia (Produção Vegetal); IF Pernambucano-Campus Barreiros, Barreiros; \\ tatiely.gomes@barreiros.ifpe.edu.br \\ ${ }^{5}$ Engenheiro Agrônomo, Doutor em Agronomia (Solo e Água); IF Goiano-Campus Urutaí, Rodovia Geraldo Silva \\ Nascimento, km 2,5; 75790-000 Urutaí, GO, Brasil; paulo.cunha@ifgoiano.edu.br
}

Recebido em: 18-11-2014; Aceito em: 28-03-2016

\begin{abstract}
The cultivar Pérola is the most widely bean cultivar cropped. In the market, it is a reference in grain size, which is related to its mass, which, in turn, is influenced by the growing conditions. The objective was to quantify the 100 -grain mass and the contents of mineral elements in the common bean cultivar Pérola, coming from the municipality of Cristalina, Goiás. It was selected 18 different areas in the city, under center pivot irrigation, where 86 samples of grains were collected during the crop harvest. The data were submitted to univariate statistical analysis, calculating maximum and minimum values, averages, amplitude of variation and coefficients of variation. It was determined the values of Pearson correlation between the contents of mineral elements in the grains. The 100-grain mass had wide range of values, from 17.30 to 33.50 grams. The composition of minerals in beans was, in descending order, $\mathrm{N}, \mathrm{K}, \mathrm{P}, \mathrm{Mg}, \mathrm{Ca}, \mathrm{S}, \mathrm{Fe}, \mathrm{Zn}, \mathrm{Mn}, \mathrm{B}, \mathrm{Cu}, \mathrm{Mo}, \mathrm{Co}$. There was a significant correlation between the mineral elements present in beans, highlighting the correlation of $\mathrm{K}$ with $\mathrm{S}$, $\mathrm{Cu}, \mathrm{Fe}, \mathrm{B}, \mathrm{Mn}, \mathrm{Co}$ and $\mathrm{Mo}$.
\end{abstract}

Additional keywords: grain exportation; mineral composition; Phaseolus vulgaris L.; 100-grain mass.

\begin{abstract}
Resumo
A cultivar Pérola é a mais plantada entre todas as cultivares de feijão. No mercado, ela é referência de tamanho de grão, o qual tem relação com sua massa, que é influenciada pelas condições de cultivo. $O$ objetivo do trabalho foi quantificar a massa de 100 grãos e os teores dos elementos minerais nos grãos de feijão, cultivar Pérola, oriundos do município de Cristalina, Goiás. Foram selecionadas 18 áreas diferentes no município, sob irrigação em sistema pivô central, nas quais foram coletadas 86 amostras de grãos, por ocasião da colheita da cultura. Os dados foram submetidos à análise estatística univariada, calculando-se valores máximos e mínimos, médias, amplitudes de variação e coeficientes de variação. Foram determinados os valores da correlação de Pearson entre os teores dos elementos minerais dos grãos. A massa de 100 grãos teve ampla amplitude de valores, variando de 17,30 a 33,50 gramas. A composição dos elementos minerais, nos grãos de feijão, foi, em ordem decrescente: $\mathrm{N}, \mathrm{K}, \mathrm{P}, \mathrm{Mg}, \mathrm{Ca}, \mathrm{S}, \mathrm{Fe}, \mathrm{Zn}, \mathrm{Mn}, \mathrm{B}, \mathrm{Cu}$, Mo e Co. Houve correlação significativa entre os elementos minerais presentes nos grãos de feijão, com destaque da correlação do $\mathrm{K}$ com S, Cu, Fe, B, Mn, Co e Mo.
\end{abstract}

Palavras-chave adicionais: composição mineral; exportação pelos grãos; massa de 100 grãos; Phaseolus vulgaris $\mathrm{L}$.

\section{Introduction}

The variability in bean grain yield is high, given the different technologies used in production, farming systems, soil fertility, among others, and these factors have an effect on grain quality in terms of its mass and the mineral elements content. The grain mass is a yield component affected by the cultivar (Lemos et al., 2004) and the other components of productivity as plant population (Stone \& Silveira, 2008) and production factors such as nitrogen fertilization (Cunha et al., 2011) and irrigation (Silva et al., 2008). This production component is directly related to the grain size (Carbonell et al., 2010), which is an important aspect for consumers 
and packaging companies (Chiorato et al., 2009). Coarse grain with sieve above 12 is a feature that promotes better market acceptance (Melo et al., 2007).

The common bean (Phaseolus vulgaris L.) is a great source of nutrients for the Brazilian population, considering that a large part of the population has the habit of consuming beans daily (Ribeiro et al., 2008). The mineral elements $\mathrm{N}, \mathrm{P}, \mathrm{K}, \mathrm{Ca}, \mathrm{Mg}, \mathrm{S}$, $\mathrm{Fe}, \mathrm{Mn}, \mathrm{B}, \mathrm{Cu}$ and $\mathrm{Zn}$ are found in the grains in different amounts, varying the conditions under which the plant is grown and the cultivar (Mesquita et al., 2007; Ribeiro et al., 2008; Salgado et al., 2011). In addition to the nutritional aspect, knowledge of the composition of these nutrients is needed in plant breeding works aimed at raising the levels thereof (Ribeiro et al., 2008), as well as subsidies for fertilizer recommendation for the culture, aimed at restoring to the soil the mineral nutrients that are exported by the grains. This study aimed to quantify the 100-grain mass and the contents of the mineral elements $\mathrm{N}, \mathrm{P}, \mathrm{K}, \mathrm{Ca}, \mathrm{Mg}, \mathrm{S}, \mathrm{B}, \mathrm{Cu}, \mathrm{Fe}, \mathrm{Mn}$, $\mathrm{Zn}, \mathrm{Co}$, and $\mathrm{Mo}$ in grains of the common bean cultivar Pérola, the most cropped Carioca bean cultivar and a reference in grain size in the market, coming from the municipality of Cristalina, Goiás.

\section{Material and methods}

The work was conducted in the fall/winter, in irrigated areas of commercial crops of common bean (Phaseolus vulgaris L.), cultivar Pérola, located in the municipality of Cristalina, Goiás, large producer of irrigated beans, the second largest producer in the country, situated in the East region, $47^{\circ} 36^{\prime} \mathrm{W}$ and $16^{\circ} 45^{\prime} \mathrm{S}$, with an average altitude of $850 \mathrm{~m}$. The predominant climate in the region is Cwa, humid mesothermal, with abundant rains in the summer, dry winters and hot summers, according to Köppen classification. The average climatic indicators are $1,600 \mathrm{~mm}$ annual rainfall, average temperature of $22{ }^{\circ} \mathrm{C}$ and $73 \%$ relative air humidity; the average temperature of the coldest months (June and July) is around $16{ }^{\circ} \mathrm{C}$. The soils in the region are classified as eutroferric Red Latosol and eutroferric Red Nitosol of clayey texture and flat-to-wavy relief.

For the collection of grains, 18 areas in the city were selected, under center pivot, in which 86 turfs were established for the development of this work. For the definition of the turfs, it was observed the homogeneity of the area, based on the development stage of the bean crop, the existence and intensity of straw, the presence and intensity of concretions, the relief and the soil color.

The collection of grains was carried out early in the bean crop harvest. It was collected grains from 10 plants taken at random within each turf to form a composite sample. Each sample was identified, being quantified the 100-grain mass and the contents of the mineral elements $\mathrm{N}, \mathrm{P}, \mathrm{K}, \mathrm{Ca}, \mathrm{Mg}, \mathrm{S}, \mathrm{B}, \mathrm{Cu}, \mathrm{Fe}, \mathrm{Mn}$, $\mathrm{Zn}, \mathrm{Co}$ and $\mathrm{Mo}$ in the grains. For $\mathrm{N}$ determination, samples underwent digestion with $\mathrm{H}_{2} \mathrm{SO}_{4}$ and the element was determined by digestion-titration (Kjeldahl). For P, K, Ca, Mg, Cu, Fe, Mn and $\mathrm{Zn}$, the samples underwent nitropercloric digestion. $P$ was determined by colorimetry with ammonium molybdate, $\mathrm{K}$ by flame photometry, $\mathrm{S}$ by turbidimetry with $\mathrm{BaCl}_{2}$. $\mathrm{Ca}, \mathrm{Mg}, \mathrm{Cu}, \mathrm{Fe}, \mathrm{Mn}$ and $\mathrm{Zn}$ were determined by atomic absorption. For $\mathrm{B}$, Co and Mo, samples were incinerated in a muffle furnace and the ash was dissolved in $\mathrm{HCl} 1 \mathrm{M}$; Co and Mo were determined by atomic absorption, and B by colorimetry with azomethine (Embrapa, 1999).

The data were submitted to univariate statistical analysis, and in the analysis of the data variability, the calculated descriptive statistical parameters were considered, as follows: maximum and minimum values, averages, amplitude of variation and coefficients of variation. It were determined the values of Pearson correlation between the contents of mineral elements in the grains. Statistical analysis was performed using the univariate procedure of the statistical program Statistical Analysis System - SAS.

\section{Results and discussions}

It was observed average 100-grain mass of $26.08 \mathrm{~g}$, with a maximum value of $33.50 \mathrm{~g}$ and minimum of $17.30 \mathrm{~g}$ (Table 1). The average value of $26.08 \mathrm{~g}$ is similar to that found by Andrade et al. (2004), $26.65 \mathrm{~g}$, but lower than those found by Ramos Junior et al. (2005), $28.50 \mathrm{~g}$, and Lemos et al. (2004), $33.10 \mathrm{~g}$, all for the cultivar Pérola. The latter is similar to the maximum value found in this work and shows that one can find higher values of 100 -grain mass for the cultivar Pérola than that reported in the description of the cultivar, $27 \mathrm{~g}$ (Pérola, 1999). Salgado et al. (2011), in tests with bean genotypes in the state of Tocantins, observed for the 100-grain mass of the common bean cultivar Pérola the value of $38.77 \mathrm{~g}$. The increase of a yield component, such as 100 -grain mass, is a plant response to maintain stable productivity when another component is impaired (Stone \& Silveira, 2008).

Higher values of 100-grain mass imply that the grain size is larger and, according to Carbonell et al. (2010), from 1998, with the launch of the cultivar Pérola, this began to be a size reference, with average size between sieves 12 and 13, becoming preferred by packaging companies and the final consumer, which define the market requirements.

The amplitude of values was high, reaching $16.20 \mathrm{~g}$, showing that the culture was in very different growing conditions, with strong influence of the production factors on this component of productivity, causing this range of values within the same cultivar. The low values of 100-grain mass may be due to poor management of irrigation, with interruption and/or reduction of water application in the stage of grain filling (Silva et al., 2008), and cases with low levels of nitrogen, possibly employed in coverage, 
as observed by Cunha et al. (2011). Lobo et al. (2012) observed higher grain mass in higher dose of nitrogen. It is noteworthy that all collections were made in irrigated areas and the management of irrigation and nitrogen fertilization is still empirical in the region, ranging from 60 to $120 \mathrm{~kg} \mathrm{ha}^{-1} \mathrm{~N}$, in coverage. In this case, the grain size is low and will surely be undervalued in the market.

Regarding the contents of chemical elements in the grain, the average values (Table 1) found for $\mathrm{N}$, $\mathrm{P}$ and $\mathrm{K}$ were, respectively, 33.21; 4.50 and $13.25 \mathrm{~g} \mathrm{~kg}^{-1}$, which shows that the chemical component of highest concentration in the grain is $\mathrm{N}$, followed by $\mathrm{K}$. Such nutritional demand order was also found by Andrade et al. (2004), showing, however, values of $39.60 ; 3.70$ and $11.00 \mathrm{~g} \mathrm{~kg}^{-1}$ for $\mathrm{N}, \mathrm{P}$ and $\mathrm{K}$, respectively, probably due to the cultivation of the common bean cultivar Pérola, being conducted in different place, soil and fertilization. According to the contents, $1,000 \mathrm{~kg}$ of grains export $33.21 ; 4.50$ and $13.25 \mathrm{~kg}$ of $\mathrm{N}, \mathrm{P}$ and $\mathrm{K}$, different values, particularly for the $\mathrm{N}$ reported by Francelli et al. (2007), $21.00 \mathrm{~kg}$, ie, $41.85 \%$ higher. It is noteworthy to report that the maximum value was $45 \mathrm{~g} \mathrm{~kg}^{-1}$, which makes this difference even greater. The high $\mathrm{N}$ content in the grain can be justified, again, as a result of cases of high doses of nitrogen fertilization in coverage.

For $\mathrm{Ca}, \mathrm{Mg}$ and $\mathrm{S}$, the average levels in the grain were very similar, being, respectively, $1.56 ; 1.74$ and $1.54 \mathrm{~g} \mathrm{~kg}^{-1}$. The same similarity occurred in the maximum and minimum values of these elements. $\mathrm{Ca}$ value is close to the values observed by Mesquita et al. (2007), of $1.16 \mathrm{~g} \mathrm{~kg}^{-1}$, average of 21 bean strains, and Fageria et al. (2008), $2.2 \mathrm{~g} \mathrm{~kg}^{-1}$, for cultivar Pérola. However, it is lower than the value of
$4.2 \mathrm{~g} \mathrm{~kg}^{1}$, reported by Francelli et al. (2007). For Mg, the average content in the grain, $1.74 \mathrm{~g} \mathrm{~kg}^{-1}$, is similar to those reported by Fageria et al. (2008), but for S, the average value of $1.54 \mathrm{~g} \mathrm{~kg}^{-1}$ is lower than those observed by Moura (1998), ranging from 2.3 to $2.6 \mathrm{~g} \mathrm{~kg}^{-1}$, and Mesquita et al. (2007), $3.6 \mathrm{~g} \mathrm{~kg}^{-1}$.

The average levels of micronutrients $\mathrm{B}, \mathrm{Cu}$, $\mathrm{Fe}, \mathrm{Mn}$ and $\mathrm{Zn}$ were, respectively, 13.28; 7.91; 63.86; 15.17 and $32.53 \mathrm{mg} \mathrm{kg}^{-1}$. The descending order of concentration is $\mathrm{Fe}, \mathrm{Zn}, \mathrm{Mn}, \mathrm{B}$ and $\mathrm{Cu}$. The average content of $B$ was two times higher than that reported by Ribeiro et al. (2008). Yet the $\mathrm{Mn}, \mathrm{Fe}$ and $\mathrm{Zn}$ contents were similar and the $\mathrm{Cu}$ content was lower when compared to Ribeiro et al. (2008) and Fageria et al. (2008). The elements $\mathrm{Fe}, \mathrm{Mn}$ and $\mathrm{Zn}$ had wide range variation, being $19 \mathrm{mg} \mathrm{kg}^{-1}$ for $\mathrm{Zn}$ and $89 \mathrm{mg} \mathrm{kg}^{-1}$ for $\mathrm{Fe}$.

According to Ribeiro et al. (2008), from the knowledge of the mineral composition of microminerals in beans, it will be possible to implement specific diets with nutritional, therapeutic and/or preventive purposes, which will allow the beans to be used as a nutraceutical food. Today, there are national and international breeding programs, with funding, for the biofortification of products and for increasing the levels of $\mathrm{Fe}$ and $\mathrm{Zn}$ in beans. Whereas $\mathrm{Zn}$ is part of approximately 300 human enzymes, the use of bean cultivars with high $\mathrm{Zn}$ content in the supplementation of diets consists in a lower-cost, practical alternative, which would not alter the feeding routine of the Brazilian people (Ribeiro et al., 2008).

The average content of $\mathrm{Co}_{\mathrm{O}}$ and $\mathrm{Mo}$ in the grains were 0.22 and $0.85 \mathrm{~g} \mathrm{~kg}^{-1}$, respectively. These minerals are required in small amounts by plants, hence the low levels in the grains.

Table 1 - Average, maximum and minimum values, amplitude of variation and coefficient of variation (CV) of the 100-grain mass (100 GM) and of the contents of mineral elements in grains of the common bean cultivar Pérola, from 86 samples of grains, coming from the municipality of Cristalina, GO.

\begin{tabular}{lrrrrr}
\hline Variable $^{1}$ & Average & Maximum & Minimum & Amplitude & C.V(\%) \\
\hline 100 GM & 26.08 & 33.50 & 17.30 & 16.20 & 5.77 \\
$\mathrm{~N}$ & 33.21 & 45.00 & 29.00 & 16.00 & 6.71 \\
$\mathrm{P}$ & 4.50 & 5.80 & 3.30 & 2.50 & 10.62 \\
$\mathrm{~K}$ & 13.25 & 15.60 & 11.60 & 4.00 & 7.03 \\
$\mathrm{Ca}$ & 1.56 & 2.10 & 1.10 & 1.00 & 14.95 \\
$\mathrm{Mg}$ & 1.74 & 2.00 & 1.40 & 0.60 & 6.91 \\
$\mathrm{~S}$ & 1.54 & 2.20 & 1.00 & 1.20 & 16.30 \\
$\mathrm{~B}$ & 13.28 & 20.00 & 8.00 & 12.00 & 18.56 \\
$\mathrm{Cu}$ & 7.91 & 12.00 & 3.00 & 9.00 & 29.12 \\
$\mathrm{Fe}$ & 63.86 & 130.00 & 41.00 & 89.00 & 24.71 \\
$\mathrm{Mn}$ & 15.17 & 60.00 & 9.00 & 51.00 & 38.62 \\
$\mathrm{Zn}$ & 32.53 & 42.00 & 23.00 & 19.00 & 11.06 \\
$\mathrm{Co}$ & 0.22 & 0.29 & 0.12 & 0.17 & 21.13 \\
$\mathrm{Mo}$ & 0.85 & 1.00 & 0.70 & 0.30 & 7.31 \\
\hline
\end{tabular}

1100 GM expressed in $\mathrm{g}$; content of macronutrients in $\mathrm{g} \mathrm{kg}^{-1}$ and of micronutrients, Co and Mo in $\mathrm{mg} \mathrm{kg}^{-1}$. 
Table 2 shows the values of the Pearson correlation between the contents of mineral elements in the beans. Several significant correlations were observed, positive or negative, between the elements. The significan correlations of the $\mathrm{K}$ element with seven other elements, being positive with $\mathrm{S}$ $\mathrm{Cu}$, Fe $(\mathrm{p}<0.0001)$ and $\mathrm{Mn}(\mathrm{p}<0.0005)$, and negative with $\mathrm{B}$, Co and $\mathrm{Mo}$ $(p<0.0001)$, are highlighted. Positive correlation between two elements means that a higher content of one implies a higher content of the other. Ribeiro et al. (2008) found a positive correlation between $\mathrm{Cu}$ and $\mathrm{Zn}$ in an evaluation of the micronutrient contents in bean cultivars, in two sites. Positive correlations between various minerals were observed by Beebe et al. (2000), in bean genotypes assessed in Colombia, noting that in breeding works, increasing the value of a mineral will result in changes in another.

Table 2 - Values of Pearson correlation between the nutrient contents of beans, from 86 samples of grains of the cultivar Pérola, coming from the municipality of Cristalina, GO.

\begin{tabular}{|c|c|c|c|c|c|c|c|c|c|c|c|c|c|}
\hline & $\mathrm{N}$ & $P$ & $\mathrm{~K}$ & $\mathrm{Ca}$ & $\mathrm{Mg}$ & $S$ & $\mathrm{Cu}$ & $\mathrm{Fe}$ & $\mathrm{Mn}$ & $\mathrm{Zn}$ & Co & Mo & $B$ \\
\hline $\mathrm{N}$ & 1.000 & $0.053^{\mathrm{ns}}$ & $0.006^{\mathrm{ns}}$ & $-0.001^{\mathrm{ns}}$ & $-0.022^{n s}$ & $0.002^{\text {ns }}$ & $0.220^{\mathrm{ns}}$ & $-0.221^{*}$ & $-0.221^{*}$ & $0.213^{\text {ns }}$ & $0.120^{\text {ns }}$ & $0.032^{\mathrm{ns}}$ & $0.013^{\text {ns }}$ \\
\hline$P$ & & 1.000 & $-0.021^{n s}$ & $0.044^{\mathrm{ns}}$ & $0.222^{*}$ & $0.059^{n s}$ & $-0.127^{\mathrm{ns}}$ & $0.231^{*}$ & $-0.097^{n s}$ & $0.522^{* *}$ & $0.265^{\star}$ & $-0.031^{\mathrm{ns}}$ & $0.114^{\mathrm{ns}}$ \\
\hline $\mathrm{K}$ & & & 1.000 & $-0.192^{n s}$ & $-0.026^{n s}$ & $0.409^{* *}$ & $0.354^{* *}$ & $0.311^{* *}$ & $0.245^{\star}$ & $0.188^{n s}$ & $-0.692^{\star *}$ & $-0.286^{* *}$ & $-0.472^{\star *}$ \\
\hline $\mathrm{Ca}$ & & & & 1.000 & $0.454^{* *}$ & $0.026^{\mathrm{ns}}$ & $0.136^{\mathrm{ns}}$ & $0.041^{\mathrm{ns}}$ & $-0.098^{n s}$ & $0.013^{\text {ns }}$ & $0.112^{\mathrm{ns}}$ & $0.067^{\text {ns }}$ & $0.147^{\mathrm{ns}}$ \\
\hline Mg & & & & & 1.000 & $-0.073^{n s}$ & $0.028^{n s}$ & $0.159^{n s}$ & $0.098^{n s}$ & $0.079^{n s}$ & $0.097^{\mathrm{ns}}$ & $-0.110^{n s}$ & $0.182^{\text {ns }}$ \\
\hline S & & & & & & 1.000 & $0.031^{\mathrm{ns}}$ & $0.265^{*}$ & $0.053^{\mathrm{ns}}$ & $-0.019^{n s}$ & $-0.335^{\star *}$ & $-0.234^{*}$ & $-0.152^{n s}$ \\
\hline $\mathrm{Cu}$ & & & & & & & 1.000 & $-0.084^{n s}$ & $0.150^{\mathrm{ns}}$ & $0.378^{\star *}$ & $-0.342^{\star *}$ & $0.009^{n s}$ & $-0.343^{* *}$ \\
\hline $\mathrm{Fe}$ & & & & & & & & 1.000 & $0.331^{* *}$ & $0.157^{\mathrm{ns}}$ & $-0.362^{\star *}$ & $-0.060^{\mathrm{ns}}$ & $-0.050^{n s}$ \\
\hline $\mathrm{Mn}$ & & & & & & & & & 1.000 & $-0.034^{n s}$ & $-0.295^{\star *}$ & $-0.024^{n s}$ & $-0.202^{n s}$ \\
\hline Zn & & & & & & & & & & 1.000 & $0.059^{n s}$ & $0.019^{n s}$ & $-0.195^{n s}$ \\
\hline Co & & & & & & & & & & & 1.000 & $0.210^{\mathrm{ns}}$ & $0.430^{\star *}$ \\
\hline Mo & & & & & & & & & & & & 1.000 & $0.100^{\mathrm{ns}}$ \\
\hline$B$ & & & & & & & & & & & & & 1.000 \\
\hline
\end{tabular}


In view of the foregoing, it can be seen that even for a standard cultivar in terms of grain size, in this case the cv. Pérola, expressed by its mass, if not given the necessary conditions for the plant regarding the different factors of production, the same would not be able to produce grains according to its market pattern, with consequent decrease in the commercial value. It is also important to note that the amounts of nutrients that are removed from the soil, by grain exportation, must be replaced through the fertilization of the culture, to maintain soil fertility in grain producing areas.

\section{Conclusions}

The 100-grain mass of the cultivar Pérola has wide range of values, ranging from 17.30 to 33.50 grams.

The quantitative composition of the mineral elements in grains of the common bean cultivar Pérola is, in descending order, $\mathrm{K}, \mathrm{P}, \mathrm{Mg}, \mathrm{Ca}, \mathrm{S}, \mathrm{Fe}, \mathrm{Zn}, \mathrm{Mn}, \mathrm{B}$, $\mathrm{Cu}, \mathrm{Mo}$ and $\mathrm{Co}$.

There is a significant correlation between the mineral elements present in beans, highlighting the positive correlation of $\mathrm{K}$ with $\mathrm{S}, \mathrm{Cu}, \mathrm{Fe}$ and $\mathrm{Mn}$, and the negative correlation with $\mathrm{B}, \mathrm{Co}$ and $\mathrm{Mo}$.

\section{References}

Andrade CAB, Patroni SMS, Clemente E; Scapin CA (2004) Produtividade e qualidade nutricional de cultivares de feijão em diferentes adubações. Ciência e Agrotecnologia 28(5):1077-1086. Doi: 10.1590/S1413-70542004000500015

Beebe S, Gonzales AV, Rengifo J (2000) Research on trace minerals in the common bean. Food and Nutrition Bulletin 21(4):387-391.

Carbonell SAM, Chiorat AF, Gonçalves JGR, Perin AEF, Carvalho CRL (2010) Tamanho do grão comercial em cultivares de feijoeiro. Ciência Rural 40(10):2067-2073. 84782010005000159

Chiorato AF, Carbonell SAM, Carvalho CR, Perina EF, Gonçalves JGR, Ramos Junior EU, Ito MA, Freitas RS, Ticelli M, Azevedo Filho JA (2009) IACJabola and IAC-Esperança: common bean cultivars for market niches. Crop Breeding and Applied Biotechnology 9:199-201.

Cunha PCR, Silveira PM, Ximenes PA, Souza RF, Alves Junior J, Nascimento JL (2011) Fontes, formas de aplicação e doses de nitrogênio em feijoeiro irrigado sob plantio direto. Pesquisa Agropecuária Tropical 41(1):80-86.

Embrapa (1999) Manual de análises químicas de solos, plantas e fertilizantes. Embrapa-CNPS. 370 p.
Fageria NK, Stone LF, Moreira AA (2008) Liming and manganese influence on common bean yield, nutrient uptake, and changes in soil chemical properties of an oxisol under no-tillage system. Journal of Plant Nutrition 39(7):1016-1025.

Francelli AL, Dourado Neto D, Tsumanuma GM (2007) Enfoque fisiológico da nutrição e adubação do feijoeiro. In: Fancelli AL, Dourado Neto D (Ed.). Feijão: estratégias de manejo para alta produtividade ESALQ. p.150-193.

Lemos LB, Oliveira RS, Palomino EC, Silva TRB (2004) Características agronômicas e tecnológicas de genótipos de feijão do grupo comercial Carioca. Pesquisa Agropecuária Brasileira 39(2):319-326.

Lobo TF, Grassi Filho H, Bull LB (2012) Efeito do nitrogênio e do lodo de esgoto nos fatores produtivos do feijoeiro. Revista Ceres 59(1):118-124.

Melo LC, Melo PGS, Faria LC, Diaz JLC, Del Peloso MJ, Rava CA, Costa JGC (2007) Interação com ambientes e estabilidade de genótipos de feijoeiro-comum na Região Centro-Sul do Brasil. Pesquisa Agropecuária Brasileira 42(5):715-723.

Mesquita FR, Correa AD, Abreu CMP, Lima R, Abreu AFB (2007) Linhagens de feijão (Phaseolus vulgaris L.): composição química e digestibilidade protéica. Ciência e Agrotecnologia 31(4):1114-1121.

Moura ACC (1998) Análises físico-químicos e enzimáticas antes e após armazenamento em grãos de feijão (Phaseolus vulgaris L.) submetidos a diferentes tempos e tipos de secagem UFLA 70 p. (Dissertação de mestrado em Ciência dos Alimentos).

Pérola: cultivar de feijão para o Rio Grande do Sul (1999) Embrapa Arroz e Feijão, Embrapa Clima Temperado, Embrapa Trigo. (Folder)

Ramos Junior EU, Lemos LB, Silva TRB (2005) Componentes da produção, produtividade de grãos e características tecnológicas de cultivares de feijão. Bragantia 64(1):75-82.

Ribeiro ND, Jost E, Cerutti T, Maziero SM, Poersch NL (2008) Composição de microminerais de feijão e aplicações para o melhoramento. Bragantia 67(2):267-273.

Salgado FHM, Fidelis RR, Carvalho GL, Santos GR, Cancellier EL, Silva GF (2011) Comportamento de genótipos de feijão, no período da entressafra, no sul do Estado do Tocantins. Bioscience Journal 27(1):52-58.

Silva MG, Arf O, Alves MC, Buzetti S (2008) Sucessão de culturas e sua influência nas propriedades físicas do solo e na produtividade do feijoeiro de inverno irrigado, em diferentes sistemas de manejo do solo. Bragantia 67(2):335-347.

Stone LF, Silveira PM (2008) Limites de competição dos componentes da produtividade de grãos do feijoeiro comum cv. Pérola. Bioscience Journal 24(2):83-88. 